\title{
MEMÓRIAS DE PROFESSORES HOMENS QUE TRABALHARAM COMO DOCENTES DE EDUCAÇÃO INFANTIL E SUAS REPRESENTAÇÕES SOCIAIS
}

\author{
MEMORIES OF MALE TEACHERS THAT WORKED IN KINDERGARTEN AND \\ SOCIAL REPRESENTATIONS
}

Josiane Peres Gonçalves ${ }^{1}$

Jéssica Barbosa Antunes ${ }^{2}$

\begin{abstract}
Resumo
O presente estudo tem como objetivo investigar as representações sociais acerca da atuação de homens como educadores na Educação Infantil e como o próprio homem docente percebe essas relações. Para a realização da pesquisa, adotamos o enfoque quantitativo para identificar quantos homens trabalhavam como docentes de Educação Infantil em Naviraí e o enfoque qualitativo para identificar as representações sociais desses homens. Ao constatar a não existência de homens professores nesta etapa da Educação Básica, optamos por pesquisar, por meio de entrevistas semiestruturadas, dois professores que atuaram na Educação Infantil, mas durante a realização da coleta de dados lecionavam em outros níveis de ensino. Os resultados indicam que a presença de professor homem está associada à disciplina, controle de sala e referencial masculino na vida de crianças que não têm a figura paterna em casa. Percebemos que as representações sociais predominantes na comunidade escolar interferem diretamente na prática desses docentes.
\end{abstract}

Palavras-chave: Representações sociais. professores homens. Educação Infantil.

\begin{abstract}
This study aims to investigate the social representations about the role of men as educators in kindergarten and as its teaching man perceives these relationships. For the research, we adopt the quantitative approach to identify how many men worked as Early Childhood Education teachers in Ashland and the qualitative approach to identify the social representations of these men. Noting the absence of men teachers in this stage of basic education, we decided to research through semi-structured interviews, two teachers who worked in kindergarten, but during the course of data collection teach at other levels of education. The results indicate that the presence of man teacher is associated with discipline, control room and male reference in the lives of children who have no father figure at home. We realize that social representations prevalent in the school community directly interfere in the practice of these teachers.
\end{abstract}

Keywords: Social representations. male teachers. Early Childhood Education.

\footnotetext{
${ }^{1}$ A autora é Doutora em Educação pela Pontifícia Universidade Católica do Rio Grande do Sul (PUCRS). Professora Adjunta da Universidade Federal de Mato Grosso do Sul Campus de Naviraí (UFMS/CPNV). Líder do Grupo de Pesquisa em Desenvolvimento, Gênero e Educação (GEPDGE). E-mail: josianeperes@zipmail.com.br

${ }^{2}$ A autora é Graduanda em Pedagogia da UFMS/CPNV. Bolsista de Iniciação Científica (PIBIC). E-mail: jessica-barbosa-antunes@hotmail.com
} 


\section{INTRODUÇÃO}

O presente estudo encontra-se vinculado ao Grupo de Pesquisa em Desenvolvimento, Gênero e Educação (GEPDGE) e busca investigar as representações sociais de professores homens sobre a atuação masculina como docentes na Educação Infantil no município de Naviraí-MS. Durante as discussões realizadas pelo grupo de pesquisa, surgiu o interesse em melhor compreender as origens da Educação Infantil, uma vez que, em outros níveis de ensino, os docentes que atuavam inicialmente eram homens e com o tempo passou a ter a predominância de mulheres. No caso da Educação Infantil, entre os integrantes do grupo de pesquisa não se tinha essa clareza, tornando-se necessário investigar a trajetória desta etapa da educação, para então entender quem eram os profissionais - homens ou mulheres - que trabalhavam e como se encontra na atualidade.

Assim, diante dos estudos teóricos realizados pelo GEPDGE, constamos que existe o predomínio de dois vieses educacionais que caracterizaram a origem da Educação Infantil no Brasil, sendo um assistencialista (para os filhos dos trabalhadores) e outro de natureza educativa (para filhos dos patrões), sendo que, em ambas as situações, aparece a questão de gênero $^{3}$ predominando entre os profissionais da educação.

Antes de comentar sobre a Educação Infantil é importante destacar que o primeiro modelo de educação formal no Brasil foi implantado por padres jesuítas e os educadores eram apenas homens, conforme Azevedo (1996). A própria educação era voltada aos meninos, uma vez que, no Brasil colonial, as mulheres eram educadas para serem boas mães e boas esposas. Para Santos (2008, p. 8), "Mesmo as oriundas de famílias mais abastadas não tinham assegurado o acesso à instrução escolarizada. A instrução era reservada aos filhos homens".

Podemos analisar que a função docente no Brasil era inicialmente desenvolvida pelo gênero masculino, os alunos que recebiam a instrução escolar também eram meninos pertencentes à elite. Para as mulheres, era destinada uma educação informal, baseada em princípios, comportamentos e deveres morais, além das atividades do lar.

\footnotetext{
${ }^{3}$ Scott (1998, p. 15) define gênero como: "Gênero é a organização social da diferença sexual. Ele não reflete a realidade biológica primeira, mas ele constrói o sentido desta realidade. A diferença sexual não é a causa originária da qual a organização social poderia derivar; ela é, antes, uma estrutura social móvel que deve ser analisada nos seus deferentes contextos históricos."
} 
Lembrando que, neste período, a educação formal era voltada às questões intelectuais, especialmente direcionadas à aquisição de conhecimentos relativos à linguagem e cálculo, ou seja, ligadas ao processo de alfabetização. Portanto, a educação mencionada refere-se ao que atualmente é conhecido como Ensino Fundamental. Então não havia uma preocupação com a educação da primeira infância ou de crianças menores de seis anos de idade. Dessa forma, cabe refletir: Como aconteceu a Educação Infantil no Brasil? A quais anseios ela visava atender? Quem eram os principais professores?

No Brasil, o atendimento a crianças pequenas em instituições começou puramente assistencial (primeiro viés da Educação Infantil), visando dar suporte às mulheres que trabalhavam fora de seus lares e as viúvas durante o século XIX. O acolhimento às crianças órfãs desamparadas foi outro fator que contribuiu para a criação dessas instituições, conforme Paschoal e Machado (2009).

De acordo com os autores mencionados, alguns setores da sociedade brasileira, como os religiosos, os empresários e educadores começaram a se preocupar com altas taxas de mortalidade infantil e desnutrição e pensaram na organização de um espaço para cuidar das crianças fora de casa. Assim, o trabalho voltado à infância no país começou com um apelo apenas assistencial, comparado a países europeus e norte-americanos que, apesar de oferecerem a assistência, tinham um planejamento pedagógico envolvido em suas ações com as crianças. Tanto que, por mais de um século, a única instituição que acolhia as crianças no Brasil era a "roda dos expostos" ou "roda dos enjeitados", onde os bebês eram abandonados de modo que a identidade do responsável não era revelada.

Somente no final do século XIX começaram no país rumores da implantação de creches no modelo jardim de infância ${ }^{4}$, conforme comentam Paschoal e Machado (2009, p. 83):

\footnotetext{
Mesmo com o trabalho desenvolvido nas casas de Misericórdia, por meio da roda dos expostos, um número significativo de creches foi criado não pelo poder público, mas exclusivamente por organizações filantrópicas. Se, por um lado, os programas de baixo custo, voltados para o atendimento às crianças pobres, surgiam no sentido de atender às mães trabalhadoras que não tinham onde deixar seus filhos, a criação dos jardins de infância foi defendida, por alguns setores da sociedade, por acreditarem que os mesmos trariam vantagens para o desenvolvimento infantil, ao mesmo tempo foi criticado por identificá-los com instituições europeias.
}

\footnotetext{
${ }^{4}$ Esse modelo será explicado posteriormente. 
Dessa forma, embora surgindo discussões sobre a questão educacional voltada ao desenvolvimento da criança, o que predominou foi o assistencialismo, pois as instituições que acompanharam o surgimento de creches e jardins de infâncias, como as religiosas e medicohigienista "[...] ambas tinham a intenção de combater o alto índice de mortalidade infantil tanto no interior da família como nas instituições de atendimento à infância." (PACHOAL e MACHADO, 2009, p. 83).

Para Farias (2005), o início de instituições voltado ao atendimento de crianças de 0 a 6 anos deu-se marcado por modificações no enredo social da organização da família e do mercado de trabalho, sem deixar de mencionar o gênero feminino ou o fato de a mulher começar a trabalhar fora de casa. Também o movimento operário influenciou por reivindicar a criação de creches para seus filhos.

Devido a muitos fatores, como o processo de implantação da industrialização no país, a inserção da mão-de-obra feminina no mercado de trabalho e a chegada dos imigrantes europeus no Brasil, os movimentos operários ganharam força. Eles começaram a se organizar nos centros urbanos mais industrializados e reivindicavam melhores condições de trabalho; dentre estas, a criação de instituições de educação e cuidados para seus filhos (PACHOAL e MACHADO, 2009, p. 83).

No decorrer da década de 1960, foi apresentado um ideal pelas feministas, de que creches e pré-escolas não deveriam ser somente privilégio das trabalhadoras, mas direito de todas as mulheres independente de suas condições financeiras ou trabalho. No Brasil, no entanto, essa teoria tomou outro rumo, conferindo vantagens às mães trabalhadoras, acreditando-se uma educação que visava à superação da realidade social vivenciada pelas crianças. Assim, a Educação Infantil, na perspectiva de creche, tinha caráter de compensação, sendo assistencialista e preocupada apenas com o 'cuidar' de crianças economicamente desfavorecidas, sem haver grandes preocupações com o 'educar' (PACHOAL E MACHADO, 2009).

Por outro lado, o segundo viés que caracteriza a Educação Infantil no Brasil, baseando-se na perspectiva educativa, refere-se aos chamados jardins da infância. Marques (2004) afirma que Froebel, um educador alemão, era considerado o pedagogo do romantismo e idealizador do "jardim-de-infancia”. Para Arce (2004, p. 10), o nome tinha como significado "[...] a constante comparação do desenvolvimento da criança com o das sementes; a criança para Froebel é como uma semente a ser cultivada". 
Também Amude e Silva (2008, p. 170) afirmam que, no ano de 1940, "Froebel funda o primeiro Jardim-de-infância (Kindergarten), destinado às crianças menores de seis anos de idade." Trata-se de um local "constituído por um centro de jogos organizado", em que se estimula a educação sensorial para a primeira infância, por meio de uma metodologia que vai do concreto para o abstrato e do simples para o complexo.

Embora fundamentada numa perspectiva religiosa, a teoria proposta por Froebel tinha também uma preocupação educativa e social, por acreditar que ao conhecer as relações entre a tríade infância, natureza e Deus é que cada indivíduo poderia se autoconhecer, compreender o seu lugar na sociedade e, consequentemente, resultar na conquista de uma sociedade melhor. (ARCE, 2004)

Diante de tal pressuposto, Froebel entendia que todo o esforço da educação e dos professores, quando se trata de crianças menores de seis anos, "[...] deve estar voltado para o favorecimento do desenvolvimento livre e espontâneo do indivíduo. Todo ser humano, tendo sido criado por Deus, também possui imensa criatividade”. (ARCE, 2004, p.10).

Quanto aos profissionais para trabalhar nos jardins-de-infância, Froebel pensava na mulher sendo a mais apta para o cargo, conforme relata Amude e Silva (2008, p. 170):

Era meta do educador a formação de mulheres, chamadas de jardineiras, para que pudessem trabalhar com as crianças. Ele acreditava que as mulheres eram naturalmente dotadas de todos os pré-requisitos necessários para a realização da educação. Elas cuidavam das crianças tal qual se cuida de um jardim. Essa mulher devia ser também mãe, símbolo do afeto e do cuidado.

É interessante notar que a Educação Infantil, segundo a perspectiva educativa, foi idealizada por um homem educador. Porém, esse mesmo pensador já acreditava que as mulheres/jardineiras é que tinham maiores condições de trabalhar com as crianças, especialmente por ser "naturalmente dotadas de todos os pré-requisitos" necessários para atuar na área da educação. Ou seja, não havia a preocupação com a formação profissional, a associação da maternidade como condição importante, por simbolizar afeto e cuidado, era o que predominava como ideal de educadoras ou jardineiras.

No Brasil os primeiros jardins de infância foram criados no final do Século XIX, em forma de "escola particular, destinada à elite", cuja finalidade era de, desde a mais tenra idade, promover o desenvolvimento intelectual, por meio de "métodos intuitivos e naturais", sempre considerando as necessidades físicas de cada criança. (KISHIMOTO, 1988, p. 58). 
Podemos notar claramente os dois vieses de Educação Infantil predominantes no Brasil, sendo: Creche, de caráter assistencial destinado aos filhos dos trabalhadores ou crianças pobres; Jardim da Infância, de caráter educativo destinado à elite ou crianças ricas ${ }^{5}$.

E quanto aos profissionais da educação, quem eram as pessoas que trabalhavam nessas duas instituições? Será que eles tinham algum tipo de formação profissional que os habilitasse a trabalhar com crianças menores de seis anos? Ao refletir sobre essas questões, Vieira (1999, p. 33) assim destaca:

Em geral, as creches eram dirigidas por médicos ou assistentes socais (ou irmãs de caridade), contando com educadoras leigas ou auxiliares, das quais eram requeridos conhecimentos nas áreas de saúde, higiene e puericultura. Nos jardins de infância, eram professores (mas, sobretudo, as professoras normalistas) os profissionais destinados à tarefa de educar e socializar os pequenos.

Ou seja, as creches tinham por objetivo apenas cuidar das crianças e atendê-las em suas necessidades físicas básicas, por meio do trabalho de "educadoras" leigas ou auxiliares. Nas instituições educativas ou jardins de infância, existiam as "professoras normalistas" que se preocupavam com a educação e socialização das crianças. No que se refere às questões de gênero, em ambos os casos existiam mulheres cuidando ou educando crianças, devido ao mito de que a mulher é "naturalmente" educadora por ser passiva, paciente, amorosa (ARCE, 2001), tendo maiores condições de atuar com crianças de 0 a 6 anos.

No aspecto legal, a Educação Infantil no Brasil teve significativos avanços somente a partir da década de 80 com a Constituição Federal de 1988, como fica firmado em seu artigo 208, o inciso IV: “[...] O dever do Estado para com a educação será efetivado mediante a garantia de oferta de creches e pré-escolas às crianças de zero a seis anos de idade" (BRASIL, 1988). E de acordo com a Lei Federal no . 9.394, de 20 de dezembro de 1996 (BRASIL, 1996), que estabelece as Diretrizes e Bases da Educação Nacional, a Educação Infantil deve ser oferecida em duas etapas, sendo a primeira para crianças de 0 a 3 anos de idade (realizada em creches ou instituições equivalentes) e a segunda para crianças entre 4 a 6 anos de idade (realizada em pré-escolas). Ocorreu, contudo, que a redação da lei foi alterada em 2006, passando a ser obrigatória a matrícula das crianças no Ensino Fundamental a partir dos 6 anos

\footnotetext{
${ }^{5}$ A ideia de "criança rica" ou "criança pobre" refere-se apenas às condições socioeconômicas. 
de idade. Em decorrência dessa alteração, a segunda etapa da Educação Infantil deve atender, então, a crianças de 4 a 5 anos de idade.

Quanto à finalidade da Educação Infantil, a LDB aponta para uma proposta pedagógica que vise ao desenvolvimento pleno dos alunos, conforme apresentado no Art. 29: "A educação infantil, primeira etapa da educação básica, tem como finalidade o desenvolvimento integral da criança até seis anos de idade, em seus aspectos físico, psicológico, intelectual e social, complementando a ação da família e da comunidade." (BRASIL, 1996).

Nesse sentido, a educação de crianças na primeira infância divide a atuação do professor em duas funções, quais sejam: a de educar, considerada a principal função do professor, e a de cuidar, que inclui dar banho, trocar fraldas, ninar e alimentar, que são cuidados inevitáveis pelo estado de dependência da criança nessa idade. Entende-se, pois, que, nessa etapa da Educação Infantil, a presença da mulher seja majoritária, reforçando a afirmativa de Louro (2012, p. 448), segundo a qual “[...] a mulher, ao atuar como professora, tem sua função relacionada ao cuidado e ao apoio maternal, o que contribuiu para a feminização do magistério".

Vale ressaltar que o chamado "processo de feminização do magistério", conforme Hypólito (1997), Louro (1989) e Gonçalves (2009), ocorreu somente em relação aos níveis mais elevados de ensino, em que inicialmente no Brasil havia somente professores homens e gradativamente as mulheres passaram a se tornar maioria, como acontece na atualidade. No caso da Educação Infantil, esse processo de "feminização" não ocorreu, uma vez que conforme apresentado anteriormente nesse estudo, tanto em creches como nos jardins de infância, as mulheres sempre foram as principais educadoras. E os principais argumentos para a preferência por mulheres trabalhando com crianças, referem-se especialmente à associação entre as habilidades maternas e femininas com o trabalho educativo que é desenvolvido no âmbito da Educação Infantil. Trata-se de representações sociais, que foram "naturalizadas", sendo difícil mudar os padrões estabelecidos socialmente. Mas o que são representações sociais?

Segundo Guareschi e Naujorks (2014), o termo representações sociais foi primeiramente descrito por Moscovici em 1961, a partir de uma análise crítica ao individualismo presente na Psicologia Social. Para tanto, pautou-se nos estudos das representações coletivas apresentadas na obra de Durkheim. Para Moscovici (2003, p.45) as 
representações eram apresentadas pela Sociologia como “[...] artifícios explanatórios, irredutíveis a qualquer análise superior”. Dessa forma, não havia uma inquietação em explicar a representação existente.

Quanto às representações coletivas, que passaram a ser denominadas por Moscovici como "representações sociais", ele assim justifica:

[...] se, no sentido clássico, as representações coletivas se constituem em um instrumento explanatório e se referem a uma classe geral de ideias e crenças (ciência, mito, religião, etc.), para nós, são fenômenos que necessitam ser descritos e explicados. São fenômenos específicos que estão relacionados com um modo particular de compreender e de se comunicar - um modo que cria tanto a realidade como o senso comum. É para enfatizar essa distinção que eu uso o termo "social" em vez de "coletivo" (MOSCOVICI, 2003, p.49).

Assim, entendemos que as representações sociais são formas utilizadas pela sociedade para compreender determinada situação e se comunicar. O que pode gerar uma representação tanto da realidade como do senso comum. Um aspecto importante sobre as representações sociais é que, para Moscovici (2003), elas não são entendidas como uma imagem fotográfica da realidade, elas são uma tradução ou uma versão desta realidade, está em constante transformação por ser dinâmica e móvel. De acordo com Abric (1998, p.28), “[...] a representação funciona como um sistema de interpretação da realidade que rege as relações dos indivíduos com seu meio físico e social, ela vai determinar seus comportamentos e suas práticas".

Podemos perceber que se as representações sociais são dinâmicas, significa que elas são construídas num contexto histórico e social e que, portanto, podem ser modificadas. Ou se existem algumas crenças predominantes em determinado contexto, que determina o comportamento e prática das pessoas, não quer dizer que será sempre assim, mas que pode haver mudanças, uma vez que as representações sociais são dinâmicas.

Diante do exposto, é possível afirmar que, para melhor entender os comportamentos, atitudes e práticas de determinado grupo social, é interessante verificar quais as representações sociais predominantes que influenciam as ações coletivas. Assim, o objetivo do presente estudo é investigar as representações dos professores homens quanto a sua atuação com crianças da Educação Infantil matriculadas na rede pública de Ensino do município de Naviraí-MS. 


\section{MEDODOLOGIA}

Após estudos teóricos realizados pelo GEPDGE sobre gênero, representações sociais, feminização do magistério, professores homens, entre outros, iniciamos a etapa da pesquisa de campo. Utilizamos como recurso de investigação, em um primeiro momento, o enfoque quantitativo, e, em um segundo momento, o enfoque qualitativo, tendo em vista que esse recurso nos permite analisar e interpretar as entrelinhas relacionadas ao objeto de pesquisa, além de "[...] obter uma maior profundidade dos dados, porque consideramos que entre o indivíduo e seu entorno há uma relação dinâmica, existindo um vínculo indissociável entre o subjetivo e o objetivo que não pode ser traduzido só por números.” (RABELO, 2013, p. 909).

Fizemos inicialmente um levantamento por meio de visitas a todos os Centros de Educação Infantil da rede municipal da cidade de Naviraí-MS, para identificar quantos homens trabalhavam nas instituições. Desde o início acreditávamos que teriam poucos professores homens, mas ficamos surpresos com o resultado ao perceber que não havia nenhum homem atuando como docente de crianças. Também constatamos que nessas instituições praticamente não existem representantes do gênero masculino adultos atuando em outras funções, como as administrativas, por exemplo. Ou seja, ao frequentar os Centros de Educação Infantil, as crianças passam a ter contatos apenas com mulheres. Portanto, o processo de desenvolvimento e aprendizagem dessas crianças, em âmbito escolar, é influenciado apenas por trabalhadoras do gênero feminino.

Diante da realidade encontrada, surgiu um problema para a realização do presente estudo, cujo objetivo é investigar as representações sociais de professores homens que atuam com crianças de Educação Infantil em Naviraí. Após diversas discussões realizadas pelo GEPDGE, entendemos que uma possibilidade seria realizar a pesquisa com dois professores de Naviraí que atualmente trabalham como docentes em outros níveis de ensino, mas que já atuaram como professores de Educação Infantil em outros momentos.

Dessa forma, adotamos como critério o fato de ambos os professores atuarem na rede pública de ensino de Naviraí (Educação Básica e Superior) e por continuarem a ter contato com a educação de crianças, tendo em vista que o professor universitário trabalha com as disciplinas que abordam temáticas relativas à Educação Infantil, bem como o estágio supervisionado, que proporciona contato direto com as crianças e com os Centros de Educação Infantil do município. Já o outro professor atua nos anos inicias do Ensino 


\section{Memórias de professores homens que trabalharam como docentes de....}

Fundamental, como alfabetizador. Além do mais, ambos os docentes residem atualmente na cidade de Naviraí.

Ao definir quais sujeitos seriam pesquisados, durante as reuniões semanais do GEPDGE, estabelecemos os critérios e elaboramos um roteiro para a realização das entrevistas semiestruturadas. Assim, foi feito contato antecipado com os dois professores e agendado um horário para a realização da coleta de dados, que ocorreu no próprio ambiente de trabalho desses docentes.

A fim de preservar a identidade dos entrevistados, optamos por identificá-los por P1 (professor que atualmente leciona no $2^{\circ}$ ano do Ensino Fundamental) e P2 (professor na universidade). Quanto à formação acadêmica, o P1 (trinta e seis anos, casado e possui uma filha), fez Magistério de quatro anos, logo em seguida cursou Pedagogia mais três anos, e especializações em Psicopedagogia, Educação Especial e Series Iniciais. O P2 (vinte e quatro anos, solteiro), cursou Pedagogia com habilitação em Educação Infantil, depois pós graduouse com mestrado em Educação e é doutorando em Educação.

Após a realização das entrevistas semiestruturadas, fizemos as transcrições e discussão coletiva dos dados, pois, conforme fomos formulando nossas análises e fundamentação teórica, paralelamente íamos apresentando para os demais integrantes do grupo, para que todos tivessem uma visão geral do andamento da pesquisa. Os resultados do presente estudo são apresentados e analisados na sequência.

\section{RESULTADOS E DISCUSSÃO}

Os resultados do estudo realizado com os dois professores entrevistados foram sistematizados por categorias, incluindo: profissão professor e Educação Infantil; percepção do professor quanto à aceitação dos pais/responsáveis e das próprias crianças; professor homem - disciplina, controle de sala e carinho de pai; relação com os demais colegas de profissão e a figura feminina;

\section{1 - Profissão Professor e Educação Infantil.}

Quando questionados sobre os motivos que levaram à escolha da profissão, os professores relataram que tiveram docentes que marcaram suas vidas e que exerceram 
influência nesta escolha, e um deles também acrescentou a influência da família como fator relevante.

[...] quando comecei a estudar na $1^{a}$ série na época não era anos iniciais era $1^{a}$ série, quem trabalhava comigo era um professor homem e eu tinha muita admiração por ele, na verdade vendo o trabalho daquele professor e tal, eu imaginava ser professor, até porque tem parentesco, em família (P1).

[...] eu tive uma professora na segunda série que ela chama M., nunca vou esquecer dela. Então ela marcou muito a minha vida em várias questões né, e eu sempre admirei ela muito, muito. E sempre quando eu penso em uma professora eu penso nela (P2).

Furlani (1998) argumenta que a escolha da profissão não se fundamenta apenas em uma decisão individual, mas está atrelada a vários fatores como os resultados obtidos no percurso escolar, privilégio social da profissão, as condições sociais e culturais da família, a oferta educacional, o capital escolar, entre outros fatores.

Primeiramente observamos que um teve como exemplo uma professora mulher, enquanto o outro admirava um professor homem, ambos dos anos iniciais do Ensino Fundamental. É interessante ressaltar que a opção em atuar na Educação Infantil aconteceu de forma diferenciada para cada professor.

De acordo com o P1, ele teve formação inicial em magistério, depois cursou Pedagogia e fez especializações em Psicopedagogia, Educação Especial e anos inicias. O contato com a Educação Infantil aconteceu muitos anos após formação, como uma pesquisa:

[...] a coordenadora chegou em mim e falou assim, você já trabalha com alfabetização e a gente precisa de um professor que tem um pouco de experiência na alfabetização pra gente fazer uma experiência, pra ver como que é um professor alfabetizador trabalhando com a educação infantil, pra ver quais são os tipos de resultados que darão $[\ldots](\mathrm{P} 1)$

Inicialmente ele resistiu à proposta, mas aceitou com a condição de desistir se não se adaptasse, conforme o relato do P1:

\footnotetext{
Até falei pra ela "olha professora, eu acho que não é muito legal não isso aí, eu grande lá no meio daquela molecada, lá e tal..." e falei "bom vou aceitar esse desafio, mas daí é o seguinte, você vai ter que me garantir que eu começo lá e se eu ver que não dá certo, é questão de duas semanas você me tira de lá”.
}

Podemos perceber, por meio dos relatos, que esse professor nunca havia trabalhado em Educação Infantil e que também não tinha intenção de atuar na área. É importante destacar que sua experiência foi em turma de crianças de cinco anos, que atualmente é denominada de 
Jardim II. Assim, o P1 não teve contato com a creche e foi a única turma de Educação Infantil em que trabalhou:

[...] foi um grupo de crianças que eu trabalhei na Educação Infantil, que eu trabalhei o pré, trabalhei o primeiro ano com essa turma, trabalhei o segundo ano, trabalhei o terceiro ano e trabalhei o quarto ano." E destaca: "Foi questão de experiência, pra ver qual o nível de conhecimento que as crianças teriam se permanecessem com um profissional até o final $(\mathrm{P} 1)$.

Ao confrontar com a experiência do outro professor, percebemos que, ao contrário do P1, o P2 não queria cursar Pedagogia e muito menos trabalhar na Educação Infantil, porém acabou por se identificar com o trabalho. E assim o P2 comenta sobre sua formação inicial:

\begin{abstract}
Eu prestei vestibular, na verdade eu não queria Pedagogia, eu queria cursar Letras né, que era outro na área da educação [...] quando chegou ao final do ano eu prestei Letras não deu muito certo, ai eu falei "vou fazer Pedagogia e vamos ver o que que acontece". Minha ideia era fazer um ano e depois mudar de curso, mas ai eu acabei gostando me identificando bastante. Quando eu prestei Pedagogia a gente vivia um processo na formação de professores que era de habilitações, que tinha Educação Infantil e anos iniciais. Como eu era muito jovem, quando eu prestei tinha 16 , então eu comecei a faculdade com 17, eu não sabia que Educação Infantil era para atuar com bebes né, com crianças menores de zero a seis anos. Então eu fiquei um ano todo. Eu falo que foi um ano enganado, achando que eu ia ser professor dos anos iniciais e aí eu ouvia o pessoal falando de bebês, falando das fases por quais a criança passa, falando de como limpar o bebê, de como dar banho, desenvolvimento infantil... e eu ficava me perguntando: "Cadê as questões né das crianças maiores?" E ai eu descobri só no final do primeiro ano que tinha dois cursos, Pedagogia vespertino na UFMS em Três Lagoas, que era o que eu fazia, que era Educação Infantil e o noturno era para os anos iniciais.
\end{abstract}

É importante destacar o fato de este professor ter ingressado em um curso com essa habilitação por engano, mas que a intenção era trabalhar com crianças maiores. Segundo relatos do mesmo professor, ele era o único aluno homem em sua turma, evidenciando o desinteresse dos homens em ingressar em cursos de licenciatura que formava professores para atuar profissionalmente na Educação Infantil. Ao mesmo tempo, podemos constatar que as representações desse professor eram de que ele não serviria para este trabalho, que foram outros fatores que o fizeram conhecer a realidade dessa área e, assim, identificar-se com o trabalho. Segundo o mesmo profissional, o estágio remunerado teve papel fundamental em sua identificação com a profissão de educador infantil: 
vivenciou um processo de estágio [...] Então eu trabalhei no estágio mais com o maternal, foram dois anos durante a graduação. Foi bem gratificante!

É interessante notar que a experiência de dois anos como professor de Educação Infantil poderia ter resultado em uma condição oposta, a de não se identificar e, consequentemente, não querer atuar nesta área após a conclusão do curso de Pedagogia. É comum acontecer com estudantes de graduação que, ao se depararem com os estágios curriculares, tendo contato direto com a futura área de atuação, perceberem que não é isso que querem e então decidem que vão se formar, porém não pretendem atuar na área. No caso do professor entrevistado foi o oposto, a experiência com a prática foi importante para ele perceber que gostava do trabalho realizado com crianças menores de cinco anos de idade. Assim, ele concluiu o curso de Pedagogia e tornou-se professor de Educação Infantil.

\section{2 - Percepção do Professor Quanto à Aceitação dos Pais/Responsáveis e das Próprias Crianças}

Quanto à aceitação das famílias em ter um professor homem, o P1 foi bem direto: "Não, na verdade nunca tive problema nenhum com pais" e acrescenta "até porque essas crianças elas já sabem ir ao banheiro sozinha né, sabem se virar sozinhas, é diferente né não é criança de creche né.” (P1). Já o P2 comenta que se surpreendeu com a reação das famílias e teve complicações apenas com dois pais:

[...] minha preocupação era a família, mas para minha surpresa a relação com a família foi muito melhor do que eu imaginava né, principalmente com as mães né, acho que no caso dos pais, que eram dois que eu tinha, era meio complicado. Teve momentos até de a diretora apresentar a atendente como professora.

Apesar de afirmar nunca ter tido problemas com os pais, é perceptível, na fala do P1, um certo receio quanto ao que os pais pensariam a respeito de sua atuação:

\footnotetext{
Até trabalhei com uma menina cadeirante, que quando ela fazia suas necessidades, num determinado tempo quem me auxiliava, eu tinha amizade com a pessoa que trabalhava nos serviços gerais e falei "Oh, você vai ter que me ajudar, porque não tem como ir ao banheiro lá e trocar a menina!" Sou homem daí é difícil né. Como que um pai vai e pegar e o.... Aí não tem jeito né.
}

Fica perceptível na fala dos dois professores esse medo da figura masculina em contato com a criança, no caso do $\mathrm{P} 2$, muitas vezes até perdendo seu posto em sala quando a atendente era apresentada em seu lugar. Vale ressaltar também toda a reconfiguração da 
prática do P1 para atender à sua aluna com necessidades especiais. Sayão (2005, p. 261) destaca, em sua pesquisa, como os obstáculos imanentes à cultura da escola exigem certas posturas dos professores, pois "[...] o corpo masculino considerado sexualmente ativo deve ser privado de contatos mais próximos com as crianças. Poucos profissionais conseguem ultrapassar tais dificuldades. Muitos preferem aderir à cultura institucional.”

Nesta perspectiva, é importante citar outro momento vivenciado pelo P2, em relação ao banho das crianças:

Na hora do banho eu preferia, pra não ter comentários, trocar... Então a professora da outra sala deixava os meninos dela comigo e eu ficava com os meus e eu passava as minhas meninas "pra" ela. Então ela dava banho em todas as meninas e eu em todos os meninos. Eu acho importante também a gente participar dessas atividades, embora tinha a recreadora pra ajudar, mas é importante não dividir as crianças.

Quanto à aceitação das crianças, os professores comentam que foram acolhidos e um relacionou ao fato de as crianças avançarem. "Então na verdade assim, o aluno só consegue avançar se... se ele avançou é sinal que ele tá se adaptando legal com o profissional, que está dentro da área, da sala. Então isso já é um grande sinal." (P1). O outro professor disse que observava o envolvimento das crianças nas atividades propostas. "Eu percebi assim que tudo o que eu me propunha a fazer junto com eles eu consegui bons resultados. Talvez não de imediato, mas eu conseguia bons resultados" (P2).

\subsection{Professor Homem: Disciplina, Controle de Sala e Carinho de Pai.}

Outro aspecto que se destaca fortemente na pesquisa com professores homens foi a relação direta da figura masculina com controle, disciplina e afetividade. Como podemos perceber na fala dos docentes:

Até porque quando a, tanto lá na Educação Infantil quanto no, primeiro, segundo, terceiro, quarto ano, a gente sendo homem, você vê que tem coisas que a maioria das crianças falta em casa é o carinho do pai. E quando eles têm um professor homem, até assim em questão de disciplina, você controla com mais facilidade porque talvez por falta dessa afetividade, você ganha campo, você sendo homem você ganha campo (P1).

Eu verifico o quanto para nós professores, o lado afetivo é da nossa profissão, isso é muito bom. E por ser homem eu também ficava muito preocupado com isso, mas ao mesmo tempo eu não deixei de demonstrar em nenhum momento o carinho o afeto 
né, com todos [...] mas pras crianças, assim de modo afetivo como eles lidaram né comigo por ser homem, eu acho que eu conseguia trazer mais a atenção deles por isso, por ser alguém não tão comum na instituição (P2).

É interessante ressaltar que, apesar de os professores abordarem a temática "afetividade" de modo diferente, eles conversam entre si quando ligam essa questão com a maior facilidade na aproximação com seus alunos, e com a capacidade de prender a atenção deles. De acordo com Veras e Ferreira (2010, p. 222) “[...] para estabelecer uma relação afetiva, é preciso que professores e estudantes estejam dispostos a esse mesmo objetivo, pois a postura que for tomada poderá influenciar na postura do outro, refletindo, assim, no processo ensino-aprendizagem." Portanto afetividade é uma relação que deve ser tomada pelo professor com responsabilidade.

Em se tratando de autoridade ou disciplina por ser homem, é importante destacar a visão diferenciada dos dois professores. O P1 comenta: “Até porque em qualquer ambiente que você, independente que você vê que tem a figura masculina a questão do respeito, até pra quem vai visitar a escola, pais e tal... é outra."

Já o P2, comenta sobre uma conversa com a diretora da instituição em que trabalhava, em que ela pergunta como ele fazia para ter domínio de seus alunos:

[...] ela falava "o que você faz com eles?" e ai uma vez ela até perguntou "você briga, você ameaça?". Eu falei "Não, não faço nada disso!" Ela falava "Então eu acho que, então é porque você é homem, você é homem então eu acho que eles te respeitam!". Mas assim, da minha experiência, eu penso assim que não é porque eu sou homem, acho que é a forma de você lidar né com as crianças, o jeito que você pensa em como ela aprende.

Em uma pesquisa realizada por Carvalho (1998) com professores homens do Brasil e de Portugal, a temática autoridade masculina foi identificada, sendo que muitos desses sujeitos investigados afirmavam que os homens tinham mais autoridade e controle de disciplina, disciplina principalmente em relação aos meninos, ou alunos do gênero masculino.

\subsection{Relação com os demais colegas de profissão e a figura feminina}

$\mathrm{Na}$ relação com os demais profissionais que compõem a comunidade escolar, os professores tiveram experiências também diferenciadas, mas ambos comentaram da estranheza do homem na Educação Infantil: 
A relação normal né, eu acho assim quando você, todo mundo 'ti' respeita como profissional. Olha você como profissional, não como professor só da Educação Infantil, profissional normal. Só que assim, só que muitas pessoas acham muito estranho, muitas das vezes, um homem lá na Educação Infantil (P1).

Já o outro professor relata com mais clareza suas percepções:

[...] foram as minhas colegas de profissão, porque lá a gente tinha umas janelas e então elas tinham que ficar abertas, por questão de estar arejada e tal... Então eu sempre pegava as pessoas olhando para dentro da minha sala para ver o que eu estava fazendo, e eu nunca percebi essa atitude com outros profissionais, com outros colegas de profissão. Eu achava muito engraçado, principalmente a cozinheira da instituição né, (risos) aí ela vinha perguntando... Aí tinha atividades, a gente fazia... aí eu levava os bebês pra fora, porque eu sempre pensei assim que berço é lugar de dormir né, e em muitas instituições infelizmente as crianças ficam muito no berço, e pouco no chão. Aí eu levava os colchões para fora, a gente tinha o momento de tomar sol e eu levava os bebês e tal. E aí ela ficava muito curiosa, o que eu ia fazer com aquelas crianças, porque o sol batia atrás né, da sala, então tinha que levar os bebês pra trás da sala (risos). Então ficava meio estranho isso, mas a atendente estava comigo e tal. E quando ela faltava era bem preocupante porque todo mundo se mobiliza, às vezes uma sala ficava sem professor, ou ficava com dois pra ter alguém comigo, sempre com a presença de uma mulher, o que era muito interessante (P2).

Apesar de o P1 não ter sentido resistência por parte de seus colegas, ainda percebemos em sua fala o receio de outros por ser homem na Educação Infantil. Já com o P2 fica bem clara a reação dos demais profissionais à sua presença. E o mais interessante é que tem um destaque exclusivo para figura feminina. Que como já vimos no decorrer deste trabalho, está diretamente relacionado à representação de que a mulher é a mais apta para atuar nessa faixa de ensino.

\section{CONSIDERAÇÕES FINAIS}

Podemos perceber, por meio da realização do presente estudo, que a Educação Infantil no Brasil traz historicamente dois grandes vieses, um foi seu princípio assistencialista, na perspectiva de creche e outro seu caráter educativo no contexto dos jardins da infância. Vale lembrar que, nesse processo, quando alcançamos a dimensão educativa, esta era direcionada a crianças financeiramente mais abastadas, enquanto que o assistencialismo predominava nas creches que atendia aos filhos de trabalhadores. E também que este modelo apenas de assistência predominou em nosso país por muitas décadas. 
Em meio a todo esse processo, foi possível notar que as mulheres sempre estiveram como protagonistas em se tratando de educação e cuidado de crianças menores de seis anos e essa realidade continua predominante, uma vez que constatamos que em Naviraí não há nenhum professor homem atuando como docente de Educação Infantil. Portanto, o processo de feminização do magistério que podemos perceber em outros níveis da Educação Básica, como Ensino Fundamental e Médio, não foi um fenômeno presente na Educação Infantil, tendo em vista que desde o início sempre contou com a presença das mulheres como principais cuidadoras ou educadoras, especialmente devido às representações sociais de que a mulher tem vocação para tal tarefa pelo fato de serem mães, portanto naturalmente educadora.

Dessa forma, entendemos, ao prosseguir do trabalho, que representações sociais são fatos construídos social e culturalmente, que as pessoas utilizam para se comunicarem. Portanto essas representações não produzem cópias idênticas à realidade são, no entanto, uma releitura dessa realidade, que pode ser feita de maneira diferente, dependendo do contexto em que se está inserido. Por isso, as representações sociais são consideradas um fenômeno dinâmico e que podem e influenciam na prática diária e nas escolhas dos indivíduos em sociedade.

Segundo a visão dos dois professores entrevistados, ficou evidente que a atuação na Educação Infantil não era objetivo principal, apesar de ambos terem formação inicial em Pedagogia, que é o único curso que habilita profissionais para atuar nessa área. Porém devemos lembrar que um professor acabou por se identificar com a área e continua diretamente ligado à Educação Infantil, como orientador de estágio supervisionado, tendo contato direto com essa realidade educacional.

É importante destacar que os entrevistados nos relataram que tiveram professores como influência na escolha da carreira como docente, em que um destaca um professor homem que teve nos anos iniciais do Ensino Fundamental, bem como a presença de professores na família, enquanto outro lembra uma professora mulher, também no período em que estudou nos anos iniciais. O que de acordo com os autores caracteriza a escolha da profissão como um processo longe de decisões exclusivamente individuais. Assim está sujeita a representações sociais.

A percepção dos professores quanto aos pais e os alunos nos fez compreender o quanto as representações socais determinaram suas práticas. O que faz com que certos estereótipos sejam estimulados, no caso, das mulheres como mais aptas ao ambiente 


\section{Memórias de professores homens que trabalharam como docentes de....}

educacional infantil. Já as crianças, segundo os professores, não tiveram reações negativas à presença de um homem e se adaptaram facilmente.

Nesse contexto, vale ressaltar a percepção desses professores quanto aos próprios colegas de profissão. De um lado, o P1 não sentiu resistência, até mesmo pelo fato de trabalhar na instituição durante um tempo considerável quando passou pela Educação Infantil. Por outro, o P2 comenta que percebia a reação dos colegas e que as representações acerca de seu trabalho fazia com que ele sempre estivesse cercado por mulheres.

Em meio a tantas representações envolvendo o trabalho do homem professor, também fica evidente a do homem dominador, ligado às questões de disciplina e respeito das crianças. Essa ideia é bem clara na fala de um dos professores bem como o reforço a essa concepção, enquanto o outro aposta em seus métodos educativos o ganho da atenção das crianças.

Enfim entendemos que as representações sociais quanto ao trabalho dos professores de Educação Infantil de Naviraí são diferentes entre os professores, bem como a percepção deles em relação à comunidade escola. Mas fica claro como essas representações (tanto deles, como dos colegas de profissão) influenciaram na prática desses professores.

\section{REFERÊNCIAS}

ABRIC, J. C. A abordagem estrutural das Representações Sociais. In: MOREIRA, A.S.P. \& OLIVEIRA, D.C. de. (Org.). Estudos interdisciplinares de Representação Social. Goiânia: AB, p.27-38. 1998.

AMUDE, A. M.; SILVA, G. B. Os jardins-de-infância: um estudo sobre a formação do ser humano a partir dos postulados de Friedrich Froebel. Teoria e Prática da Educação, v.11, n.2, p.168-172, maio/ago., 2008.

ARCE, A. O jogo e o desenvolvimento infantil na teoria da atividade e no pensamento educacional de Friedrich Froebel. Cadernos Cedes, Campinas, vol. 24, n. 62, p. 9-25, abr., 2004.

. Documentação oficial e o mito da educadora nata da educação infantil. Cadernos de Pesquisa, n.113, p. 167-184, jul., 2001.

AZEVEDO, F. de. A Cultura Brasileira: introdução ao estudo da cultura no Brasil. 6 ed. Rio de Janeiro: Editora UFRJ; Brasília: Editora UnB, 1996.

BRASIL. Constituição da República Federativa do Brasil. Brasília, DF: Senado

Federal, 1988, 305 p. 
BRASIL. MEC. Lei de Diretrizes e Bases da Educação Nacional. Brasília: MEC, 1996.

MEC. Lei n. 11.274, 6 de fevereiro de 2006. Altera a redação dos arts. 29, 30, 32 e 87 da Lei n. 9.394, de 20 de dezembro de 1996, que estabelece as diretrizes e bases para a educação nacional, dispondo sobre a duração de 9 (nove) anos para o ensino fundamental, com matrícula obrigatória a partir dos 6 (seis) anos de idade. Diário Oficial da União, Brasília, DF, 7 fev. 2006.

CARVALHO, M. P. de. Vozes masculinas numa profissão feminina. Rev. Estud. Fem., Florianópolis, v. 06, n. 02, p. 406-422. jul/dez. 1998. Disponível em: $<$ http://educa.fcc.org.br/scielo.php?script=sci_arttext\&pid=S0104026X1998000200011\&lng=es\&nrm=iso>. Acesso em: 29 de Abril de 2014.

FARIAS, S. C. A colônia em movimento: fortuna e família no cotidiano colonial. Rio de Janeiro: Nova Fronteira, 2005.

FURLANI, Lúcia T. M. A claridade da noite: os alunos do ensino superior noturno. São Paulo: Cortez, 184p.1998.

GUARESCHI, T.; NAUJORKS, M. I. As representações sociais de professores acerca da aprendizagem de alunos com distúrbios globais do desenvolvimento. GT: Educação Especial / n.15. Reunião Anual da ANPED. 2014. Disponível em:

<http://29reuniao.anped.org.br/trabalhos/trabalho/GT15-2192--Int.pdf> Acesso em: 19 de Junho de 2014.

GONÇALVES, J. P. O perfil profissional e representações de bem-estar docente e gênero em homens que tiveram carreiras bem-sucedidas no magistério. 2009. $232 \mathrm{f}$. Tese (Doutorado em Educação) - Pontifícia Universidade Católica do Rio Grande do Sul, PUC/RS, Porto Alegre, 2009.

HYPÓLITO, A. L. M. Trabalho docente, classe social e relações de gênero. Coleção Magistério, Formação e Trabalho Pedagógico. Campinas, SP: Papirus, 1997.

LOURO, G. L. Mulheres na Sala de Aula. In: PRIORE. M. D.; PINSK. B. C. (Org.). História das mulheres no Brasil. São Paulo: Contexto, 2012.

. Magistério de $1^{\circ}$ grau: um trabalho de mulher. Educação e Realidade, Porto Alegre, v. 14, n. 2, p. 31- 39, jul./dez., 1989.

KISHIMOTO, T. M. A pré-escola em São Paulo (1877 a 1940). São Paulo: Loyola, 1988.

MARQUES, V. R. B. História da Educação. Curitiba, PR. Editora IESDE, 2004.

MOSCOVICI, S. Representações sociais: investigações em psicologia social. Petrópolis, RJ: Vozes, 2003. 
PASCHOAL, J. D.; MACHADO, M. C. G. A história da educação infantil no Brasil: avanços, retrocessos e desafios dessa modalidade educacional. Revista HISTEDBR On-line, Campinas, n.33, p.78-95, - ISSN: 1676-2584, mar. 2009.

RABELO, A. O. Professores discriminados: um estudo sobre os docentes do sexo masculino nas séries iniciais do ensino fundamental. Educação e Pesquisa, São Paulo, v.39, n.4, p. 907925 out./dez. 2013.

SAYÃO, D. T. Relações de gênero e trabalho docente na educação infantil: um estudo de professores em creches. 273 f. Tese (Doutorado) - Universidade Federal de Santa Catarina, centro de ciências da educação, Florianópolis. 2005.

SANTOS, V. M. As tutoras e a educação dos órfãos da elite setecentista sergipana. Anais do $V$ Congresso Brasileiro de História da Educação: o ensino e a pesquisa em História da Educação... Aracaju: UFS/UNIT, 2008. Disponível em:

<http://www.sbhe.org.br/novo/congressos/cbhe5/pdf/434.pdf >. Acesso em: 20 abr. 2014.

SCOTT, J. Gênero: uma categoria útil de análise histórica. Educação e Realidade, Porto Alegre, v. 2, n. 20, p. 71-99, jul./dez. 1998.

VERAS, R. da S.; Ferreira, S. P. A. A afetividade na relação professor-aluno e suas implicações na aprendizagem, em contexto universitário. Educar em Revista, Curitiba, Brasil, n. 38, p. 219-235, Editora UFPR, set./dez. 2010.

VIEIRA, L. M. F. A formação profissional da Educação Infantil no Brasil no contexto da legislação, das políticas e da realidade do atendimento. Pro-posições, São Paulo, v. 10, n. 1 (28), p. 28-39, mar. 1999. 